Portland State University

PDXScholar

Engineering and Technology Management

Faculty Publications and Presentations

$12-1-2017$

\title{
Contextual Differentiation of Absorptive Capacity: Empirical and Conceptual Development
}

\author{
Marina Dabic \\ University of Zagreb \\ Ernest Vlačić \\ NOVAMINA
}

Tugrul Unsal Daim

Portland State University, tugrul@etm.pdx.edu

Follow this and additional works at: https://pdxscholar.library.pdx.edu/etm_fac

Part of the Engineering Commons

Let us know how access to this document benefits you.

\section{Citation Details}

M. Dabic, E. Vlacic and T. Daim, "Contextual Differentiation of Absorptive Capacity: Empirical and Conceptual Development," 2017 Portland International Conference on Management of Engineering and Technology (PICMET), Portland, OR, 2017, pp. 1-8.

This Article is brought to you for free and open access. It has been accepted for inclusion in Engineering and Technology Management Faculty Publications and Presentations by an authorized administrator of PDXScholar. Please contact us if we can make this document more accessible: pdxscholar@pdx.edu. 


\title{
Contextual Differentiation of Absorptive Capacity: Empirical and Conceptual Development
}

\author{
Marina Dabic ${ }^{1,2}$, Ernest Vlačić ${ }^{3}$, Tugrul Daim ${ }^{4}$ \\ ${ }^{1}$ University of Zagreb, Faculty of Economics and Business, Zagreb, Croatia \\ ${ }^{2}$ Nottingham Trent University, Nottingham, UK \\ ${ }_{3}^{3}$ NOVAMINA, Zagreb, Croatia \\ ${ }^{4}$ Portland State University, Department of Engineering \& Technology, Portland, USA
}

\begin{abstract}
This paper is focused on the research and operationalization of the absorption capacity in technology driven firms with a particular focus on their technology based innovation performances, which is widely recognised as a means of achieving and maintaining the firms' competitive advantage. Although research in the field of absorption capacity was globally initiated more than two and a half decades ago, the same was not at all the case with Eastern European firms. Considering that, the research objective of this paper arises: what is the level of the absorptive capacity in technology driven Croatian firms and how does it catalyse their innovation outputs? Our specific objectives are to measure the integrated level of the absorptive capacity (ACAP) with respect to all its constituent components; assimilation, acquisition, transformation and exploitation. Such an ACAP measured value will be tabulated against the innovation outputs of firms and their business performances. To achieve these objectives a selected population of more than 200 Croatian firms that are dealing technology development was defined as a sample and asked to fill the questionnaire. Forty five of them that have fully responded were tested against formulated hypothesis ultimately proving that the higher level of ACAP is somehow positively driving their innovation performances.
\end{abstract}

\section{INTRODUCTION}

In research for an appropriate term to describe the organizational capacity to recognize the value of new external information (knowledge), and to assimilate and implement it for commercial purposes, in [1], Cohen and Levinthal conceived the idiom 'absorption capacity'. In 1990, the definition was lifted up to the ability of a firm to identify the value of new, external information, assimilate it, and apply it to commercial ends' and they saw it as largely a function of the firm's level of prior related knowledge. According to the widely acknowledged model, the absorption capacity of a company consists of four fundamental complementary components: acquisition, assimilation, transformation and exploitation [2]. In terms of the effect produced within the firm, the first two components, acquisition and assimilation, belong to the category of potential absorption capacity of enterprises (potential absorptive capacity - PACAP), and the other two, transformation and exploitation, belong to the category of realized absorptive capacity of enterprises (Realized absorptive capacity - RACAP). ACAP is often explored in an innovation context for firms normally focused on technological innovation development. Initial models of ACAP's were frequently challenged and as a consequence a number of new models have evolved. These emerging models were created for multiple reasons, but two of them are crucial. The first one represents a need to observe the operationalization of ACAP to match the researchers' paradigm, while the other represents an evolution in understanding of the ACAP scientific base and the need to upgrade or modify previous models in the light of new knowledge.

After introduction a literature review is presented. The theoretical overview ends with a hypothesis formulation followed by a presentation of the applied methodology, including the definition of sample and scope as well. Thirdly, we analysed and discussed results. In fourth section we draw the corresponding conclusions. The paper ended with a description of identified limitations in the research implementation, recommendations for a practical use of produced knowledge and suggestions of opportunities for further research are given.

\section{LITERATURE REVIEW}

Cohen and Levinthal [3] argued that, while research and development generates innovation, it also develops the ability of companies to identify, assimilate and exploit knowledge from the external environment - the so-called learning or absorptive capacity. Their work was recognized and continued by others $[4][5][6]$, where they recognized the opportunity to research ACAP in a wider scope, outside the segment of direct investment in R\&D. That influenced a number of researchers to focus their work on the implementation of ACAP's for organizations of various types, particularly firms. [2] pointed out that absorption capacity is recognized as a key dynamic capability which can strongly influence the nature and sustainability of competitive advantage. In recent years, scientists have used the concept of ACAP in studies of various organizational phenomena [2], in strategic management [7] and technology management [8][9][10].

An extended model adapted from [11][5][6], presented in [12] was selected, and it is presented in Fig. 1. Among other models, this one is particularly relevant in the light of this paper because its outputs are innovation and firm's performance, which are the two components that we are focused on in research. 


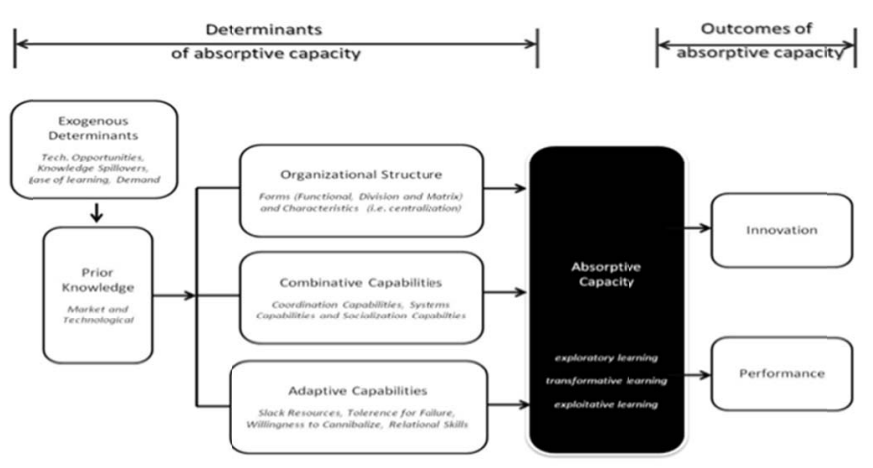

Fig. 1. Expanded ACAP-a model, adapted from [11][5][6]; presented in[12]

\section{A. Hypothesis Formulation}

Theoretical discussions suggest that a developed ACAP and the ability to innovate are important factors in achieving competitive advantage [3][2]. Various studies [13][14][15] suggest that this relationship is particularly important for sustainable competitive advantage (SCA) of firms. [16] recognised that a developed ACAP, which is bounded by the knowledge transfer capabilities, is critical for achieving and maintaining the firm's SCA.

[17] operationalizes ACAP where it is claimed that there exists a positive correlation of ACAP and a firm's performance. This is done from the perspective of understanding the technological capabilities of firms and loyalty of its customers. [18] researched 303 firms from SME's U.S. membership database and comfirmed positive and direct relationships between absorptive capacity and time-based manufacturing practices.

On the one hand, ACAP is closely associated with innovation process, and on the other, with the systematic management of knowledge. [19] concluded that with progress in the understanding of the co-evolutionary, the absorption capacity of knowledge becomes critical input for the achievement of global sustainable competitive advantage. Therefore it is straightforward that ACAP is closely and inextricably tied to the achievement of sustainable competitive advantage (OCD) in firms.

Based on the literature review of ACAP and its contribution to firms' performance, and related to the objectives of this study, we set out the first hypothesis of this paper.

\section{H1. Higher level of absorptive capacity positively influences firm performances.}

This hypothesis' intention is to understand whether the level of ACAP is positively correlated with the firm's performance, in other words, do firms where higher levels of ACAP's are measured achieve better business performance. The empirical links and interactions between the level of ACAP, organizational innovation and performance have been systematically sought throughout the years. For example, [20] explored the interaction of ACAP and the intensity of innovation processes initiation, with particular emphasis on available external knowledge. Direct links of ACAP levels and the innovative firm's capacity in its work is also explored by [21]. In parts of their research, [13] look at the correlation between the ACAP and the successfulness of innovation processes by means of initiating radical and incremental types of innovations. Their work is performed in the light of RBV views, in which the abilities of the firm (ACAP related) are compared with indicators of its performance. Specifically, the measure of a firm's performance in the work by [13] is ROA (return on assets).

In his two studies [22][23] Bahli explored the links between ACAP-levels in firms and the number of generated innovative processes. In the second paper [23] refer to the specificity and uncertainty of launching innovative processes associated with the level of ACAP. Furthermore, [22] examined the type of generated innovation (radical or incremental), which may depend on the existing level of ACAP's components (acquisition, assimilation, transformation and exploitation).

[14] carried out extensive research in which he explores links between two ACAP's basic components (PACAP, RACAP) and the firm's performance. In his work, Rahatkin [14] evaluates an extended range of firm's performance indicators; market orientation, balance in the relationship of price/product differentiation, sales growth, customer loyalty and other. Thus, based on the theoretical review of ACAP's role in a firm's innovation process, and related to the objective of this paper, next corresponding hypothesis is formulated.

H2: Higher level of absorptive capacity positively influences triggering of innovation processes

In testing this hypothesis we started from the assumption that firms which we established to possess a higher level of absorption capacity performed better at initiating innovation processes, because they recognize the innovation potential better, and are subsequently able to embed it in their activities.

From the preliminary examination of theoretical background it might be logical to conclude that the higher the level of innovation activities performed in the firm, the higher the odds are of this firm performing successfully. In a recent paper Kalay and Lynn (2015) [24] modify this statement slightly and claim that the innovation strategy is positively correlated with successful innovation in firms. One of the biggest barriers to the commercialization of innovations can be strong competition. Therefore, due to the effect of cannibalization, [25] state that not each innovation or launch of innovative products should be automatically successful. As a measure of successful innovation a number of performance indicators in several categories can be considered. The first category is productivity, which amongst others can be quantified through a frequently used model CDM offered by [26], followed by the employment category [27][28], the financial indicators [29][30] and others. [31] confirmed that collaborative networks positively influenced product innovation. Finally, in [32] it is concluded that innovation, as a direct result of knowledge or its combination, is considered to be a fundamental component of entrepreneurship and a key element of business success. Based on the review of a part of the research that links the innovation processes and performance of an enterprise, we state our third hypothesis. 


\section{H3. Higher frequency of initiated innovation processes} positively influences firm performances.

In testing of this hypothesis we assumed a realistic situation where the innovation processes may be halted or interrupted in their implementation, thus ultimately not resulting in sustainable commercialization of products. Another undesirable scenario influences the process negatively, which is when an already launched or commercialized product/service has not been successful on the market.

The fourth hypothesis is set as validating hypothesis which is influenced by previous three.

H4: There is a positive influence in frequency of initiated innovation processes as mediator in relationship between absorptive capacity and the firm performance.

By testing this hypothesis we've learned whether there is a direct relationship between observed variables, in other words whether the number of initiated innovation processes acts as mediator in rACAP and PosUsp relationship and with which intensity. The mediation process is presented in Fig. 2.

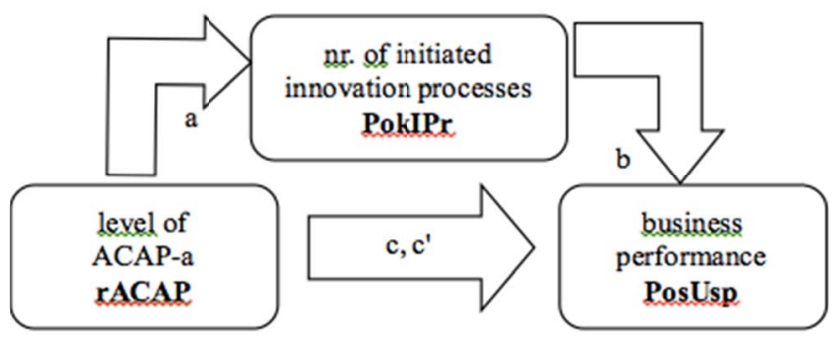

Fig. 2. Mediation Process

Following this paper's hypotheses' formulation, and taking the selected model of ACAP (fig. 1) into consideration, an empirical model for research was created as represented in fig. 3.

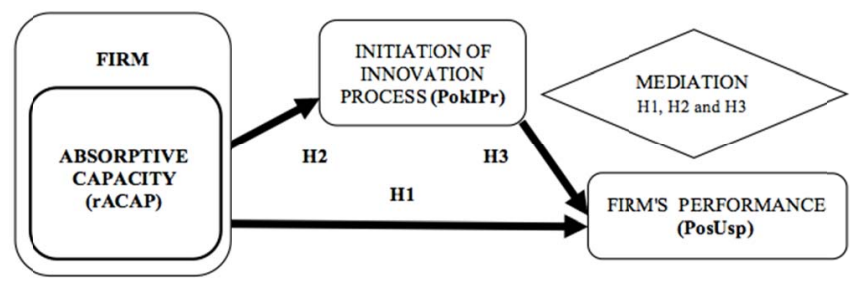

Fig. 3. Empirical research model with allocated hypotheses

\section{MethodologicAl ApPROACH}

The research sample includes firms that are classified in Croatia according to the National classification code NKD2007 which corresponds to NACE classification. Targeted population of firms represents a purposive sample that is specifically identified. From a database of the Croatian Chamber of Economy (CCE) some two hundred $(\mathrm{n}=200)$ mostly small and medium size (from 10 up to 250) firms were selected for distribution of the questionnaire. Continuous conducting or intention of firms to conduct internal technology innovation processes was used as selection criteria in order to select firms as eligible candidates. Thus, for those firms that were selected it was assumed that they had already carried out innovation activities or invested in R\&D, and had subsequently launched an innovation process. For a number of them the innovation activity had to be determined and confirmed via direct phone calls. Typology and nature of firm's ownership were not taken into account. As for the response, 53 firms filled in completely their questionnaires, and as a result 45 were deemed completed and fully usable, representing a return of $22,5 \%$ after filtration and verification. Out of these 45 , five firms did not fill in the number of performed innovations question, thus reducing to 40 the population eligible for the mediation analysis.

Most of the selected firms are deriving from technology sector, the ICT at first place, followed by engineering companies in various sectors, technology development firms, and firms that are regularly innovating to maintain their competitive edge. Due the relatively quantitative small sample a mixed methodology was applied as well. It included 4 conducted in-depth interviews of responded firms' CEOs followed by the analysis of their five years financial performances.

ACAP level was ultimately measured by formulating 27 questions as a composition of four basic components, which are according to [2] representing four basic ACAP constituents, the acquisition (9 questions), assimilation (6), transformation (8) and the exploitation (4). All questions were constructed using 1-8 Likert scale thus avoiding the middle answer, and finally grouping them in two basic sub-categories of ACAP, the PACAP and RACAP.

Measurement of firm's business performances was conducted by examining the firms about their income and profit trends through the last five years in order to position them on the scale from 1 to 7 . Merging these two values has produced a 1 to 7 score, where the ' 7 ' represents a highly business performing company which grew in profits and revenues in the past five years and ' 1 ' represents the opposite, extremely low performing firm.

The number of innovative products technology developments processes is determined by requiring firms to specifically note how frequently they have initiated it in the span of last five years. Interestingly and surprisingly, collected results have shown that, although categorised as technology developers, 5 of firms did not innovate their products in the last five years at all.

Main variables used in the analysis with their descriptions are presented in the table 1 . Four already mentioned variables that are not shown in a table are acquisition (ACAPaq), assimilation (ACAPas), transformation (ACAPtr) and exploitation (ACAPex), which were measured by arithmetic mean that furthermore produced the integrated ACAP value.

TABLE I. QUESTIONNAIRE ACAP VALUES RESULTS

\begin{tabular}{|c|l|l|}
\hline Variable & \multicolumn{1}{|c|}{ Measured } & \multicolumn{1}{c|}{ Description } \\
\hline pACAP & $\begin{array}{l}\text { Likert scale 1-8, 15 } \\
\text { questions }\end{array}$ & $\begin{array}{l}\text { The level of the potential ACAP in firms; arithmetic mean value of the } \\
\text { composite ACQUISITION + ASSIMILATION, }\end{array}$ \\
\hline raACAP & $\begin{array}{l}\text { Likert scale 1-8,12 } \\
\text { questions }\end{array}$ & $\begin{array}{l}\text { The level of the realized ACAP in firms; arithmetic mean value of the } \\
\text { composite TRANSFORMATION + EXPLOITATION }\end{array}$ \\
\hline rACAP & $\begin{array}{l}\text { Likert scale 1-8, total } \\
27 \text { questions }\end{array}$ & $\begin{array}{l}\text { The level of ACAP in firms; arithmetic mean value of the composite } \\
\text { pACAP + raACAP }\end{array}$ \\
\hline PokIRr & $\begin{array}{l}0=0,1=1, \text { from 2 to } 4 \\
=2, \text { from } 5 \text { to } 10=3, \\
\text { and }>10=4\end{array}$ & $\begin{array}{l}\text { Number of initiated innovation process in firms; numeric variable in the } \\
\text { rarge from 0-4, determined in a time frame of 5 years. }\end{array}$ \\
\hline PosUsp & $\begin{array}{l}\text { Composite of } \\
\text { variables, from 1 to } 7\end{array}$ & $\begin{array}{l}\text { Composite of variables that includes revenues and profits. Determined in the } \\
\text { time frame of last } 5 \text { year and measured by achieved levels of revenues and } \\
\text { profits spanning 7 grades between strongly negative, up to strongly positive. }\end{array}$ \\
\hline
\end{tabular}


Formulated hypotheses were tested by use of descriptive statistics with the linear regression analysis applied. Thanks to the sample size $>35$, the applied regression analysis used the Pearson product moment correlation coefficient $(\rho)$, while the practical relevance of resultant models is proved via the correlation ratio according to the determination coefficient, by applying the Chaddock scale [33]. To determine whether any of the differences between the means are statistically significant a one-way ANOVA with reported 'p' value was used, determining statistical significance for values $<0.05$.

As an essential part of the mediation analysis, a multiple regression and a bootstrap procedure were applied to determine the mediation effect of variable PokIPr. Because of somewhat smaller number of testing samples instead of applying the Sobel test the verification of mediation analysis results was performed by use of bootstrapping with 1000 iterations.

\section{RESEARCH RESULTS AND DISCUSSION}

\section{A. ACAP level}

A results summary table of absorption capacity level measurement is shown in Table 2. The total measured value of ACAP is 6.04, which per se does not directly reveal much about the meaning of absorptive capacity, but is highly important as grounds for conduction of the research. On the other side it may present an important indicator for potential future cross comparison research which may be applied on different national firm's populations or eventual transnational researches.

TABLE II. QUESTIONNAIRE ACAP VALUES RESULTS

\begin{tabular}{|c|c|c|c|}
\hline \multicolumn{3}{|c|}{ ACAP, total: 6.04} \\
\hline PACAP, total: & 6,12 & \multicolumn{2}{|c|}{ RACAP, total: 5,97} \\
\hline ACQUISITION & ASSIMILATION & TRANSFORMATION & EXPLOITATION \\
5.87 & 6.37 & 5.88 & 6.06 \\
\hline
\end{tabular}

From the results in the table we may observe that Croatian firms scored higher with PACAP (6.12) than RACAP (5.97), which in general tells that they are foremost capable to deal with the identification and the internationalization of the idea, rather than transforming the idea into a viable innovative product or service. Difference in observing PACAP associated values of acquisition (5.87) and assimilation (6.37) indicates that firm are less capable to identify and embrace new ideas or initiatives for innovation (5.78) in comparison with assimilating and internalize them properly (6.37). That reveals the chronic cultural lack of cooperative spirit among these firms and their inertial behaviour in still operating captured in some way closed siloes.

\section{Descriptive Statistics}

Table 3. presents an overview of applied methodology with allocated regression and mediation analyses, as well as definition of variables.

TABLE III. APPLIED METHODOLOGY AND VARIABLES DESCRIPTION

\begin{tabular}{|c|l|l|l|}
\hline H & \multicolumn{1}{|c|}{ Method } & \multicolumn{1}{c|}{ Independent Variable } & \multicolumn{1}{c|}{ Dependent variable } \\
\hline H1 & Simple linear regression & level of ACAP-a, $\boldsymbol{r A C A P}$ & firm's performance PosUsp \\
\hline H2 & Simple linear regression & level of ACAP-a, $\boldsymbol{r A C A P}$ & nr. of processes initiated $\boldsymbol{P o k I P r}$ \\
\hline H3 & Simple linear regression & nr. of processes initiated PokIPr & firm's performance PosUsp \\
\hline H4 & $\begin{array}{l}\text { Mediation analysis } \\
\text { (multiple regression) }\end{array}$ & $\begin{array}{l}\boldsymbol{r A C A P} \text { as dependent and PokIPr} \text { as } \\
\text { mediator }\end{array}$ & firm's performance PosUsp \\
\hline
\end{tabular}

A summary of results after the application of ANOVA regression analyses is presented in Table 4 , where besides the regression formulas, the $\rho, \mathrm{r} 2$ and $\mathrm{p}$ values are presented for each applied regression. A hypothesis testing result is given in a table as well.

TABLE IV. REGRESSION ANALYSES TEST RESULTS
\begin{tabular}{|c|l|c|c|c|c|}
\hline Hip. & \multicolumn{1}{|c|}{ Regression formula } & $\rho$ & $\mathbf{r}^{2}$ & $\mathbf{p}$ & test result \\
\hline H1 & PosUsp $=0.7145 \times$ rACAP +0.9185 & 0.714 & 0.538 & 0.000 & confirmed \\
\hline H2 & PokIPr $=0.6064 \times$ rACAP -1.1218 & 0.512 & 0.263 & 0.001 & confirmed \\
\hline H3 & PosUsp $=0.5211 \times$ PokIPr +3.9228 & 0.521 & 0.409 & 0.000 & confirmed \\
\hline
\end{tabular}

As is evident from Table 4, all three regression hypotheses are tested positively and were confirmed. The regression coefficients according to the Chaddock scale are all $>0.5$ and the significance $p$ values are very low. That mean that in testing formulated hypothesis we have identified rather strong correlation between measured variables. In simple words that means that in examined technology performing firms in Croatia the ACAP level plays important role in their innovative performance and in business success particularly. In addition, the higher the innovative output measured by initiated innovation processes is, the higher is their business performance.

\section{Mediation analysis}

As part of the mediation analysis a multiple regression of dependent variable PosUsp and two dependent variables $\boldsymbol{r A C A P}$ and $\boldsymbol{P o k I P r}$ was performed The latest PokIPr variable acts as a mediator variable. The results are presented in table 5 . together with included results of applied bootstrap verification function.

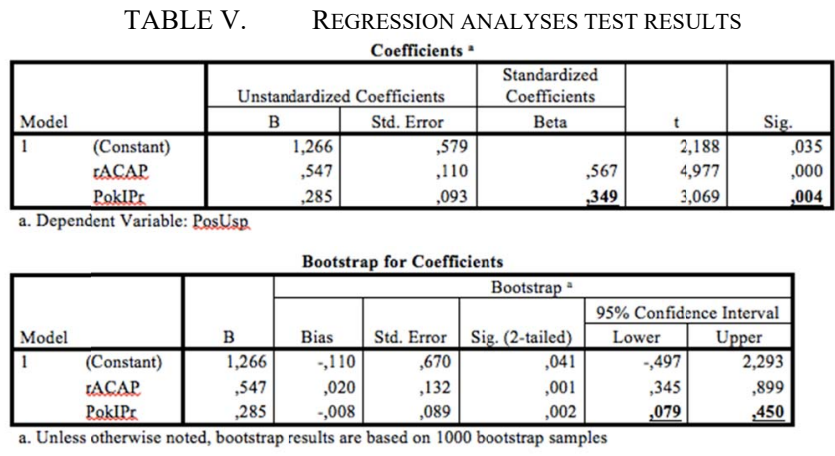

As a result, applied bootstrapping is presenting values of the confidence intervals that for the variable PokIPr does not shows zeros but it lays somewhere between 0.079 and 0.450 . That means that a rather weaker positive indirect influence of $\boldsymbol{P o k I P r}$ in reaching positive business performances of firms is identified. While on the other hand, as visible in the tables, there's no intense weakening of the significance PokIPr noted. Thus the result of the analysis confirms a weak positive mediation PokIPr in rACAP and PosUsp relation, which provides the last hypothesis confirmation.

\begin{tabular}{|c|c|c|}
\hline Hip. & Mediation & test result \\
\hline H4 & Exists: it is positive and weaker & confirmed \\
\hline
\end{tabular}

In other words that indicates that ACAP has positive effect on firm's performance while at the same time it is weakly positively moderated by the number of running innovation processes. 


\section{ANALYSYS AND DiSCUSSION}

\section{A. Questionnaire output}

In order to answer our research question on what the measured level of absorptive capacity in Croatian technology driven firms is and how it influences their innovation and firm's performances outputs, a segmental analysis of the produced results was done. The result obtained by overall ACAP measurement represents a numeric value (6.04). It yet does not reflect a specific meaning outside the context of this research, mainly because this is the first study that has operationalized ACAP in technology driven Croatian firms. Notwithstanding, for the purpose of this research, the produced value of ACAP's bears extreme importance, not least because it allows comparability with its constituent components and application of statistical analysis. The fact that PACAP (6.12) has produced higher value than RACAP (5.97) implies that Croatian companies perceive themselves as organizations that have developed innovative potential, but are not able to use it in a rather effective way for the purpose of developing a new product or service. Furthermore, the results of the survey suggest that Croatian companies are well aware of the fact that they have to act innovatively, which is one of their critical success factors for achieving competitive advantage. However they do not consider themselves as exceptionally capable for the practical application of existing or otherwise available knowledge/ideas to be transformed into innovative products or services. They conduct a market and technological audit on a regular basis, observe development trends and even, to some extent, possess necessary resources and knowledge for innovation. Yet in the PACAP segment, as well as in the segment of transformation, a feeling or need to strengthen the cooperation with organizations of institutional and noninstitutional environments is not well developed.

\section{Descriptive Statistics - Regression Analysis}

In the regression analysis for the purpose of testing hypotheses H1, H2 and $\mathrm{H} 3$ (Figure 4), the correlation of dependent and independent variables shows somewhat stronger positive links. As a result of testing $\mathrm{H} 1$ we established that a higher level of ACAP positively influences the business performances of technology driven firms. Also, by testing H2, we have determined that a higher level of ACAP's has a positive impact on the number of initiated innovation processes in Croatian firms. Finally testing results of $\mathrm{H} 3$ have almost logically determined that the higher the initiated innovation processes are performed the higher the business performance of firms is. For the technology driven Croatian firms these findings are suggesting that possessing higher levels of ACAP for the firm is important and it currently presents a notable impact on business success. That also suggests that in that optics that ACAP should be treated with particular care and actions should be implemented in order to improve it on continuous base.

Lastly applied mediation analysis tells that there's weaker positive mediation of the number of innovative processes performed in ACAP vs. business performance relation, which is also understandable and even welcomed. Because strong mediation would indicate that the business success is rather grounded on the innovation processes performing rather than the ACAP level, thus marginalizing the role of ACAP against the innovation processes.

\section{CONCLUSIONS}

In an attempt to answer the research questions and achieve the set objectives a combined tailored methodology approach was used and applied to a population of technology driven Croatian firms. The research was conducted in the period of national economy recovery from the world crisis that struck the global economy in 2008, including that one of Croatia. To satisfy the relevance and significance criteria in pattern selection, firms with proven innovating activity were primarily identified and researched in this paper.

In general, while conducting research the produced resulted were within expected boundaries. Measurement of ACAP and its components have produced a result with an absolute value that is rather indicative at the moment, because similar studies have not yet been performed in a Croatian environment. Nevertheless, the values produced by ACAP measurement are extremely important in understanding the relationship between various components of a firm's innovation performance, and may be used in future cross comparison or benchmarking research efforts.

The results produced in this paper have unveiled that examined Croatian firms are struggling with several problems in their innovation processes performance. One of the most evident is a lack of ability to identify new knowledge to be used as a trigger for activation of the innovation process. With this paper we dare to indicate that such identified major drawback is rooted in the cultural and social aspects of the Croatian business environment. On the other hand, through hypotheses testing, this research has determined and confirmed, although with different levels of correlation and significance, that various interlaced relationships of absorptive capacity and other processes exist in firms. From presented results one may conclude that Croatian firm's ACAP is strongly correlated with business performance or financial results, much more than with innovation performances. That finding is interesting, because innovation does not necessarily produce positive performance results, particularly since the innovation process is usually long lasting and the results come with a certain time delay. Several researches made by $\mathrm{CDM}$ on several EU countries has demonstrated that investments in $R \& D /$ innovation may result in lower moderate performance results or sometimes even negative. "In some countries, such as Cyprus, Slovakia, Greece, Latvia, Lithuania, Poland, Romania and Croatia, R\&D efforts rely predominantly on the public sector - higher education and government. This indicates that conditions for business R\&D investment are still insufficiently attractive in those countries " [34]. This is particularly valid for the SME population which represents a significant share of the sample used for this research. Rather positive outcome of this study may be grounded on the fact that the examined population was naturally knowledge and technology development oriented one.

From these empirical considerations it may be concluded that there is a very strong and unbreakable bond between the levels of ACAP and the implementation of the innovation process in the firms. The reason for this is, among others, that 
in the implementation of an innovation a number of ACAP elements are intensively used as a medium.

At the end, such a measured ACAP represents a level of intensity and structured efforts that organisations are implementing in firms, and less intensely, reflects the influence on their business performance. Nevertheless, the postulate is that firms must innovate in order to maintain their competitive edge, and led by the ancient one 'navigare necesse est' we may conclude 'innovare necesse est'.

\section{PRACTICAL CONTRIBUTION AND IMPLEMENTATION}

The produced results will be presented to a wider audience in order to match existing platforms for guidance of national innovation strategies and national smart specialisation strategies [35], [36]. Thus they may be used to shape an updated action plan with the objective of improving the current state of innovation performances in Croatian firms. Such approach shells require a broader involvement of several organizations, individuals who are relevant experts in the field and firms as well.

It was already in the process of creation of this work that a certain level of visibility was made available to the involved participants. Hence the attractiveness, applicability and importance of the researched topic were confirmed, either by firms or institutional bodies in Croatia. As previously mentioned, the research was performed in apparently postcrisis times and new turmoil in global economy. Examining innovation capacities, particularly from the ACAP perspective, a considerable scope opens up for its practical implementation in improving the current situation regarding both the firms and the institutional framework, which is obligated to foster national innovation policies. From the academic perspective, research on this topic of this volume represents a practical contribution and opens a wide area for future ACAP research, which should ideally be oriented towards future operationalization of ACAP's by using new or upgraded models, rather than pure theoretical research.

A part of the institutional framework representatives expressed an interest in presenting the topic at upcoming events; not only for the population of SMEs, but also larger companies or even policy makers. Additional interest in the institutional framework was identified, which is expressed through the ability to directly present the topic to a selected targeted population of firms, e.g. via competitiveness clusters or other associations, regardless of whether there were planned meetings/events.

\section{LIMITATIONS AND FUTURE RESEACRH}

\section{Limitation in research}

As in other places, the number of distributed questionnaires to firms in Croatia has been growing constantly, saturating the persons who fill them in. Although the final response of 40 fully completed questionnaires can be considered as a good result, it was achieved only after a several round of stimulation and persuasion of firms' representatives to fill them in and submit them.
Furthermore, one should be aware that no matter how much effort has been invested into the process of making questions clear to a large population of subjects; it should be kept in mind that respondents have different skills, different hierarchical positions in companies and varying cognitive characteristics. Therefore, we assume that they could understand the same questions in different ways and that in the conducted empirical analysis their responses were treated and evaluated equally.

\section{Future research}

Empirical research results deriving from the operational part of this thesis provide a solid methodological and knowledge ground for future research of the absorptive
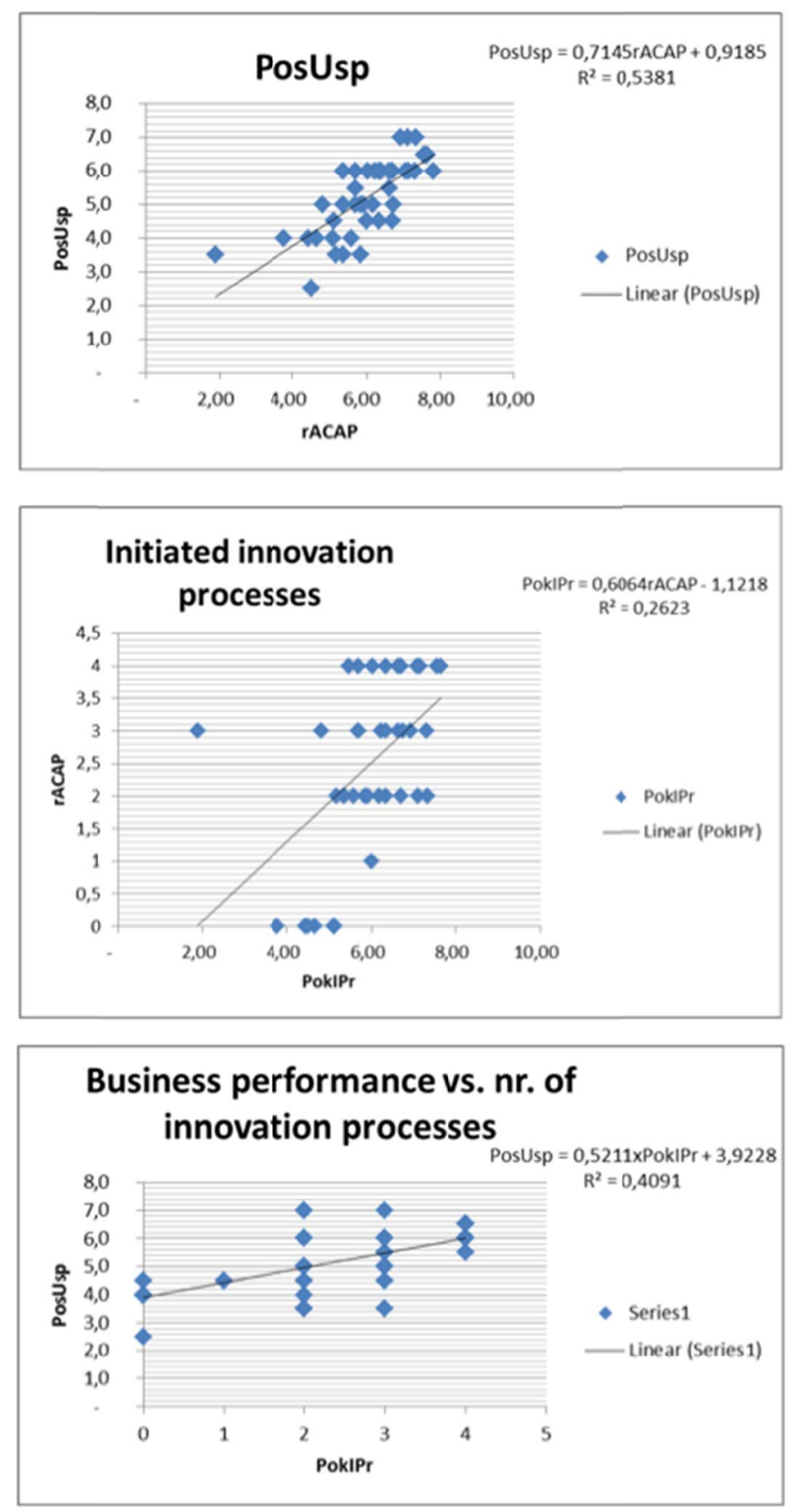

Fig. 4. Regression analysis 
capacity in Croatia. Hence there is wide room for the development of future research on this topic, and not only in the scope of national research efforts, because the produced results now provide an opportunity for comparative research with regional or broader international coverage. Thus the results may be comparable with other EU (and outside EU) countries where an extension of this research could be applied as well.

A follow up research based on findings of this work can be focused for example on combinatorial relations and the correlation of absorption capacity with other business elements in firms, and its interaction with the national institutional framework. With this approach, a measured ACAP can be placed in a more precise context of the of firm's performance, through the measurement of the construct at a higher resolution and accuracy, which can be achieved by adopting different composite variables as performance indicators.

It is also feasible to upgrade this empirical research for Croatian firms by connecting ACAP with some key economicbusiness interdisciplinary areas such as strategic management, human resources management, management of finance and others. The same is valid for trans-disciplinary areas such as innovation management, systematic knowledge management in firms, and the very closely related project management.

\section{REFERENCES}

[1] W. M. Cohen and D. A. Levinthal, "Innovation and learning: the two faces of R \& D," Econ. J., vol. 99, no. 397, pp. 569-596, 1989.

[2] S. A. Zahra and G. George, "Absorptive capacity: A review, reconceptualization, and extension," Acad. Manage. Rev., vol. 27, no. 2, pp. 185-203, 2002.

[3] W. M. Cohen and D. A. Levinthal, "Absorptive capacity: A new perspective on learning and innovation," Adm. Sci. Q., pp. 128-152, 1990.

[4] F. A. Van Den Bosch, R. Van Wijk, and H. W. Volberda, "Absorptive capacity: antecedents, models and outcomes," 2003.

[5] P. J. Lane, B. R. Koka, and S. Pathak, "The reification of absorptive capacity: A critical review and rejuvenation of the construct," Acad. Manage. Rev., vol. 31, no. 4, pp. 833-863, 2006.

[6] U. Lichtenthaler and E. Lichtenthaler, "A capability-based framework for open innovation: Complementing absorptive capacity," J. Manag. Stud., vol. 46, no. 8, pp. 1315-1338, 2009.

[7] J. Nahapiet and S. Ghoshal, "Social capital, intellectual capital, and the organizational advantage," Acad. Manage. Rev., vol. 23, no. 2, pp. 242266, 1998.

[8] M. A. Schilling, "Technological lockout: An integrative model of the economic and strategic factors driving technology success and failure," Acad. Manage. Rev., vol. 23, no. 2, pp. 267-284, 1998.

[9] H. Rush, J. Bessant, and M. Hobday, "Assessing the technological capabilities of firms: developing a policy tool," RD Manag., vol. 37, no. 3, pp. 221-236, 2007.

[10] P. Fernando Robles, C. M. Rodriguez, J. A. Wise, and C. Ruy Martinez, "Strategic capabilities in exporting: an examination of the performance of Mexican firms," Manag. Decis., vol. 51, no. 8, pp. 1643-1663, 2013.

[11] F. A. Van Den Bosch, H. W. Volberda, and M. De Boer, "Coevolution of firm absorptive capacity and knowledge environment: Organizational forms and combinative capabilities," Organ. Sci., vol. 10, no. 5, pp. $551-568,1999$.

[12] A. L. L. de Araújo, "Advancing a Dynamic Model of Absorptive Capacity: Which Organizational Antecedents Matter?," 2010.
[13] B. Forés and C. Camisón, "Does incremental and radical innovation performance depend on different types of knowledge accumulation capabilities and organizational size?," J. Bus. Res., vol. 69, no. 2, pp. 831-848, 2016.

[14] S. Rakthin, "Contextual Differentiation Of Absorptive Capacity: Empirical And Conceptual Development," MIchigan State University, USA, 2013.

[15] Z. X. Mei and H. Y. Feng, "Empirical Analysis on Relationship among Social Capital, Absorptive Capacity and Innovative Performance of High-tech SMEs in China."

[16] V. Chauvet and C. Guiot-BP, "Absorptive capacity and knowledge transfer propensity: towards the obtaining of a competitive advantage," Organ. Behav. Hum. Decis. Process., vol. 82, no. 1, pp. 150-159, 2002.

[17] N. Tzokas, Y. A. Kim, H. Akbar, and H. Al-Dajani, "Absorptive capacity and performance: The role of customer relationship and technological capabilities in high-tech SMEs," Ind. Mark. Manag., vol. 47, pp. 134-142, 2015.

[18] Q. Tu, M. A. Vonderembse, T. S. Ragu-Nathan, and T. W. Sharkey, "Absorptive capacity: Enhancing the assimilation of time-based manufacturing practices," J. Oper. Manag., vol. 24, no. 5, pp. 692-710, 2006.

[19] M. González-Loureiro, M. Dabic, and F. Puig, "Global organizations and supply chain: New research avenues in the international human resource management," Int. J. Phys. Distrib. Logist. Manag., vol. 44, no. 8/9, pp. 689-712, 2014.

[20] H.-F. Lin, J.-Q. Su, and A. Higgins, "How dynamic capabilities affect adoption of management innovations," J. Bus. Res., vol. 69, no. 2, pp. 862-876, 2016.

[21] S.-H. Liao, C.-C. Wu, D.-C. Hu, and G. A. Tsuei, "Knowledge acquisition, absorptive capacity, and innovation capability: an empirical study of Taiwan's knowledge-intensive industries," Proceedings of World Academy of Science: Engineering \& technology, vol. 11, p. 13, 2009.

[22] B. Bahli, "Enabling innovation in information technology outsourcing: An empirical study," in ACIS 2012: Location, location, location: Proceedings of the 23rd Australasian Conference on Information Systems 2012, 2012, pp. 1-8.

[23] B. Bahli, C. Wettenberg, H. P. Borgman, and H. Heier, "The role of absorptive capacity in information technology outsourcing and innovation performance: a moderated mediation analysis," in System Sciences (HICSS), 2013 46th Hawaii International Conference on, 2013, pp. 4635-4644.

[24] F. Kalay and G. Lynn, "The Impact of Strategic Innovation Management Practices on Firm Innovation Performance," Res. J. Bus. Manag., vol. 2, no. 3, pp. 412-429, 2015.

[25] D. Isogawa, K. Nishikawa, and H. Ohashi, "New-to-Market Product Innovation and Firm Performance: Evidence from a firm-level innovation survey in Japan," Citeseer, 2012.

[26] B. Crépon, E. Duguet, and J. Mairessec, "Research, Innovation And Productivi [Ty: An Econometric Analysis At The Firm Level," Econ. Innov. New Technol., vol. 7, no. 2, pp. 115-158, 1998.

[27] S. Lachenmaier and H. Rottmann, "Effects of innovation on employment: A dynamic panel analysis," Int. J. Ind. Organ., vol. 29, no. 2, pp. 210-220, 2011.

[28] R. Harrison, J. Jaumandreu, J. Mairesse, and B. Peters, "Does innovation stimulate employment? A firm-level analysis using comparable microdata from four European countries," National Bureau of Economic Research, 2008.

[29] P. Gibcus and R. G. M. Kemp, "Strategy and small firm performance. Zoetermeer," EIM reports: Research Report, 2003.

[30] K. W. Artz, P. M. Norman, D. E. Hatfield, and L. B. Cardinal, "A longitudinal study of the impact of R\&D, patents, and product innovation on firm performance," J. Prod. Innov. Manag., vol. 27, no. 5, pp. $725-740,2010$.

[31] M. J. Nieto and L. Santamaría, "The importance of diverse collaborative networks for the novelty of product innovation," Technovation, vol. 27, no. 6, pp. 367-377, 2007. 
[32] M. Dabic, V. Andrijevic-Matovac, and T. Kiessling "AN EXPLORATORY STUDY OF INNOVATION IN CROATIA AFTER INDEPENDENCE/Raziskovalna studija inovacij na Hrvaskem po neodvisnosti - ProQuest." [Online]. Available: http://search.proquest.com/openview/791562ad18613282a19d32cf5833d b1f/1.pdf?pq-origsite=gscholar\&cbl=28719. [Accessed: 01-Jan-2017].

[33] R. E. Chaddock, Principles and methods of statistics. Houghton Mifflin Company, 1925.
[34] "Europe 2020 indicators - research and development," Eurostat Statistics Explained.

[35] MINGO, "Strategija Poticanja Inovacija Republike Hrvatske 2014. 2020," Nar. Novine Repub. Hrvat., vol. 153, no. 74, 2014.

[36] MINGO, "Strategija pametne specijalizacije Republike Hrvatske za razdoblje 2016.-2020," Nar. Novine Repub. Hrvat., vol. 2, no. 2, 2016 